\title{
Antimicrobial activity of four essential oils extracted from plants commonly used in traditional medicine against some clinical strains
}

\author{
SAID OULKHEIR ${ }^{1 *}$, HADIA BOUMARIEM ${ }^{1}$, HANANE DAND ${ }^{1}$, MOHAMED AGHROUCH ${ }^{2}$, \\ KHADIJA OUNINE ${ }^{3}$, ALLAL DOUIRA ${ }^{4}$, SMAIL CHADLI ${ }^{1}$
}

\author{
${ }^{1}$ High Institute of Nursing Professions and Health Techniques \\ ISPITS \\ Agadir, Morocco \\ ${ }^{2}$ Laboratory of Medical Analysis \\ Hospital Hassan II, Agadir, Morocco \\ ${ }^{3}$ Laboratory of Applied Microbiology \\ Department of Biology, Faculty of Sciences \\ Ibn Tofail University \\ Box 133, 14000 Kénitra, Morocco \\ ${ }^{4}$ Laboratory of Botany and Protection of the Plants \\ Department of Biology, Faculty of Sciences \\ Ibn Tofail University \\ Box 133, 14000 Kénitra, Morocco \\ *corresponding author: phone: +212 665935 050, e-mail: oulkheirs@gmail.com
}

\section{Summary}

Introduction: Recently, efforts regarding the discovery of the effectual components of plants possessing antimicrobial properties are advanced. Herbal essential oils are widely used for treatment of various diseases, and they play an important role in healthcare considerations.

Objective: This study aims to evaluate the effectiveness of Cinnamomum verum, Eucalyptus globulus, Lavandula angustifolia and Mentha pulegium essential oils against Candida albicans and some pathogenic bacteria.

Methods: The antibacterial activity of four essential oils (EOs) against different microbial strains was evaluated using the disk diffusion method as well as determination of the minimal inhibitory concentration 
(MIC), and bactericidal concentration (MBC). For Candida albicans, the MFC of the plant oils was determined using a macro broth dilution assay. A range of concentrations (50 to $0.2 \mathrm{mg} / \mathrm{ml}$ ) were prepared in Mueller Hinton Broth medium in flasks. Tween $80(0.01 \% v / v)$ was included to enhance oil solubility. Each flask was inoculated with $10^{8} \mathrm{CFU} / \mathrm{ml}$ of $\mathrm{C}$. albicans. The flasks were incubated at $35^{\circ} \mathrm{C}$ for 48 hours. From each flask $13 \mu \mathrm{l}$ of culture was inoculated onto Mueller-Hinton Agar plates and incubated at $35^{\circ} \mathrm{C}$ for $48 \mathrm{~h}$. The plates were observed and the MFC was determined as the lowest concentration of plant oil completely inhibiting the growth of $C$. albicans.

Results: The obtained results showed that all bacteria and yeasts tested were sensitive to cinnamon essential oil with an inhibition zone ranging from 22 to $39.33 \mathrm{~mm}$ and a MIC ranging from $0.20 \mathrm{mg} / \mathrm{ml}$ to $1.56 \mathrm{mg} / \mathrm{ml}$. At low concentrations ranging from 0.2 to $3.13 \mathrm{mg} / \mathrm{ml}$, this essential oil has shown the most important bactericidal effect. Eucalyptus essential oil showed the highest inhibitory effect on Staphylococcus aureus with a diameter of $21.33 \pm 1.15 \mathrm{~mm}$. The antibacterial effect of mint indicates that the most sensitive bacterium is A. boumannii. However, S. enteritidis, C. albicans, K. pneumoni and P. aeruginosa are resistant germs whose inhibition diameter varies from $7.33 \pm 1.15 \mathrm{~mm}$ to $11.33 \pm 1.15 \mathrm{~mm}$. Lavender EO has an inhibitory effect against $S$. aureus $(20.67 \pm 1.15 \mathrm{~mm})$ and an intermediate effect against Streptococcus pyogenes, Serratia marcescens and Enterococcus faecalis.

Conclusions: The antibacterial activity of essential oils, especially those of cinnamon against the strains studied, supports their potential use as a remedy against infectious microbial diseases.

Key words: essential oils, antimicrobial activity, Candida albicans, pathogenic bacteria

Słowa kluczowe: olejki eteryczne, aktywność antybakteryjna, Candida albicans, bakterie patogeniczne

\section{INTRODUCTION}

Infectious diseases, particularly those caused by bacterial microorganisms, are still among the top causes of mortality in the world [1]. During the last decades, rapid evolution and spread of resistance among clinically important bacterial species have been observed. Due to this growing increase of resistance, many antimicrobial agents are losing their efficacy [2-4]. The development of antibiotics bacterial resistance demonstrates the necessity of novel antibacterial agents to combat bacteria that have become resistant to currently used antibiotics. Thus, the quest for safer alternatives has led to studies on plant extracts, such as essential oils. Indeed, it has been known that aromatic plants and spices, as well as their essential oils, have varying degrees of antimicrobial activity, for this reason, extracts from these plants can be used to delay or inhibit the growth of pathogenic or spoilage microorganisms $[5,6]$. EOs (essential oils) are a complex mixture of natural, volatile, and aromatic compounds synthesized by aromatic plants that have been often used in traditional medicine [7]. They are classified as monoterpenes and sesquiterpenes, according to the number of isoprene units, monoterpenes being the most abundant in EOs components.

Several researchers have also investigated the antimicrobial properties of plant extracts and many plants have been examined so far [8-10]. Various essential oils of different plants such as thyme, oregano, mint, cinnamon, lavander, and clove, have been observed to possess strong antimicrobial properties [11]. Therefore, the present study was conducted to determine the antibacterial and antifungal activity of four essential oils: Cinnamomum verum, Eucalyptus globulus, Lavandula angustifolia and Mentha pulegium, against Candida albicans and some pathogenic bacteria isolated from Biomedical Laboratory of HSSAN II Hospital, Agadir, Morocco.

\section{MATERIALS AND METHODS}

\section{Plant material}

Cinnamomum verum, Eucalyptus globulus, Lavandula angustifolia and Mentha pulegium used in this work, for extraction of essential oils, were obtained from Herbalist in the Agadir province (tab. 1).

\section{Extraction of essential oils}

Fresh leaves of E. globules, M. pulegium, flowers of $L$. angustifolia and barks of C. verum were subjected to hydrodistillation (HD) for $3 \mathrm{~h}$ with $500 \mathrm{ml}$ 


\section{Table 1}

Main botanical characters, traditional use and therapeutic benefits of the four essential oils studied

\begin{tabular}{|c|c|c|c|c|}
\hline $\begin{array}{l}\text { Common } \\
\text { name }\end{array}$ & Botanical name & Botanical characters & Traditional use & Therapeutic benefits \\
\hline Cinnamon & $\begin{array}{l}\text { Cinnamomum } \\
\text { verum }\end{array}$ & $\begin{array}{l}\text { Small tree } 10-15 \mathrm{~m} \text { tall with persistent foliage. } \\
\text { The bark is gray outside and reddish inside. The } \\
\text { large leathery leaves, } 10 \mathrm{~cm} \text { long in dark green } \\
\text { glossy, are pointed oval shaped at the end. The } \\
\text { yellowish white flowers are small and all hairy } \\
\text { (covered with hair) in long, narrow clusters } \\
\text { emerging at the axils of the leaves. The fruits are } \\
\text { small red brown berries. }\end{array}$ & $\begin{array}{l}\text { Can be taken as a decoction } \\
\text { of dried bark, as an infusion } \\
\text { or in the form of essential oil. }\end{array}$ & $\begin{array}{l}\text { Has mainly antioxidant, antibacterial } \\
\text { and anti-inflammatory properties. } \\
\text { It is used mainly against colds, flu, } \\
\text { digestive disorders, as it stimulates } \\
\text { blood circulation and immune } \\
\text { system. }\end{array}$ \\
\hline
\end{tabular}

mall red brown berries.

It is a tree native to Tasmania (Australia). Eucalyptus globulus is 30 to 60 meters tall, with a smooth trunk and white to gray color. Its bark is easily detached in long strips. The young leaves are waxy, oval, clear, opposite and sessile. But these are leaves growing on the old branches that are officinal because they are the only ones

Eucalyptus Eucalyptus to have essence pockets on the underside. The globulus flowers, visible in spring, are born in the axils of the leaves, the calyx has the shape of a bumpy top whose broad part is covered by a operculum which is detached at the moment of the flowering revealing numerous stamens. The fruit is the angular capsule of the chalice, it contains two types of seeds.
This plant is effective for treating The usual forms of colds, flus and sore throat. She traditional use of eucalyptus acts as a potent expectorant are infusions, leaf decoctions used in the treatment of lung and fumigations. infections, including bronchitis and pneumonia.

The flowers in decoction soothe hysteria, ingested as they are, they would also be effective to calm cough and asthma. The essential

Lavender prefers siliceous soils. It is a shrub with four-branched twigs. The discreet foliage is

Lavender

Lavandula angustifolia gray or gray green. The flowers are small, dark purple, united in short pedunculate, compact, quadrangular, topped with a bundle of large purple sterile bracts. The fruit is a tetra-alkene.
Can be taken as a decoction of leaves, or in the form of essential oil. oil is a valuable remedy for first aid, it is antiseptic, accelerates the healing of burns and wounds and calms inflammations due to insect stings. They use it to treat scabies and lice. In massage, it is applied on the head to calm its evils, to relax and tone the nervous system

It is a perennial by rhizomes, low, 10 to 55 $\mathrm{cm}$ high, frequent in humid environments, which exhale a strong aromatic odor. The leafy, quadrangular, spreading or lying stems emit adventitious roots very easily on the underside of the nodes. The flowering stems are more or entire (slightly serrated) and provided with a

Can be taken as an infusion or in the form of essential oil. short petiole. The flowers, which appear from July to late September, are pink lilacs sometimes white and are grouped in the axils of leaves in glomeruli (false whorls) staggered along the stem. The fruits are achenes.
Traditionally used in herbal medicine to help digestion and relieve flatulent dyspepsia and intestinal colic. In infusion, it has antispasmodic and stimulating properties. Applied on a tissue at the temples has relieves headaches. It is also used to relieve nervous disorders. 
distilled water using a Clevenger-type apparatus according to the European Pharmacopoeia [12]. The extracted oil were collected and dried over anhydrous sodium sulfate, then stored in sealed glass vials in a refrigerator at $4^{\circ} \mathrm{C}$ prior to analysis.

\section{Antimicrobial activities assays Microorganisms and media culture}

The microorganisms used in this study were: Escherichia coli, Pseudomonas aeruginosa, Klebsiella pneumoniae, Proteus mirabilis, Acinetobacter baumannii, Serratia marcescens, Salmonella enteritidis, Enterococcus faecalis, Streptococcus pyogenes, Staphylococcus aureus and one strain of Candida albicans. They were provided by the laboratory of medical analyzes of Hassan II Hospital of Agadir-Morocco.

Media used for carrying out this study were Brain Heart Infusion Broth (Biokar diagnostics), Mueller Hinton Broth (MHB (Biokar diagnostics) and Mueller-Hinton Agar (MHA) ((Biokar diagnostics). Stock cultures were maintained at $4{ }^{\circ} \mathrm{C}$ on nutrient agar slants for bacteria and Sabouraud agar for Candida albicans. Active cultures for experiments were prepared by transferring a loopful of culture to $5 \mathrm{ml}$ of Brain Heart Infusion Broth and incubated at $37^{\circ} \mathrm{C}$ for 24 hours.

\section{Essential oils activity assay Disk diffusion assay}

Screening of essential oils for antimicrobial activity was done by the disk diffusion method. It was performed using an $18 \mathrm{~h}$ culture at $37^{\circ} \mathrm{C}$ for bacteria and $48 \mathrm{~h}$ culture at $35^{\circ} \mathrm{C}$ for C. albicans in $10 \mathrm{ml}$ of Mueller Hinton Broth. Cultures were adjusted to approximately $1,510^{6} \mathrm{CFU} / \mathrm{ml}$, to turbidity comparable with that of McFarland 0.5 standard with sterile saline solution. Two $\mathrm{ml}$ of inoculum is deposited on each Petri dish for both control and test plates. After impregnation for 5 minutes, the excess inoculum is removed by aspiration. Under aseptic conditions, filter paper disks (Whatman $6 \mathrm{~mm}$ dia) were impregnated with $10 \mu \mathrm{l}$ of different essential oils and placed on the agar surface. Antibiotics used as controls are those to which the bacteria studied showed resistance (Gentamicine (CN), Cefoxitin (FOX), Vancomycin (NA), Imipenem (IMP)). All Petri dishes were sealed with parafilm to avoid eventual evaporation of test samples. The plates were left for $30 \mathrm{~min}$ at room temperature to allow the diffusion of oil, and then they were incubated at $37^{\circ} \mathrm{C}$. After the incubation period, the zone of inhibition was measured with a calliper. Studies were performed in triplicate, and statistical analysis was done with the aid of xlstat752. The results were expressed as mean $\pm S D$. The results are expressed according to three levels of activity: resistant $(\mathrm{D}<12 \mathrm{~mm})$, intermediate $(12 \mathrm{~mm}<\mathrm{D}>19 \mathrm{~mm})$ and sensitive $(\mathrm{D}>19 \mathrm{~mm})$ [13].

\section{Minimum inhibitory concentration, minimum bactericidal and fungicidal concentration}

The Minimum Inhibitory Concentration (MIC) values were evaluated by using the broth serial dilution method. The stock solution of each essential oil is prepared in the following manner: $100 \mu \mathrm{l}$ of the $\mathrm{HE}$ is added to $900 \mu \mathrm{l}$ of the Mueller Hinton Broth (MHB medium) supplemented with Tween 80 . Serial dilutions of the high concentration were made in sterile test tubes contained (MHB + Tween $80(0.01 \% v / v)$, to develop a concentration range from 50 to $0.2 \mathrm{mg} / \mathrm{ml}$. After pre-culturing, microorganism suspensions $\left(10^{8} \mathrm{CFU} / \mathrm{ml}\right)$ were inoculated into fresh broth (MHB + Tween $80(0.01 \%$ $v / v$ ) containing one EO. After the incubation at $37^{\circ} \mathrm{C}$ for bacteria and $35^{\circ} \mathrm{C}$ for $C$. albicans $\mathrm{MIC}$ values were determined as the lowest concentration of the essential oils at which the completely inhibited the visible growth of microorganisms.

After MIC determination, $13 \mu \mathrm{l}$ from clear culture of the MICs test were placed on Mueller-Hinton Agar (MHA). MBC and MFC values were defined as the lowest concentration of sample which resulted in $\geq 99.9 \%$ kill of the initial inoculum.

Ethical approval: The conducted research is not related to either human or animal use.

\section{RESULTS}

The antimicrobial activity of four essential oils against all microorganisms is summarized in table 2. The results revealed that the diameters of inhibition, generated by the essential oils, in comparison with those produced by the antibiotics are very variable, according to the oil used. Indeed, the essential oil of C. verum produces inhibition diameters much greater than those produced by Gentamicin, Vancomycin, Cefoxitin and Imipenem. In contrast, the antibacterial activity of essential oils of E. globulus, $L$. angustifolia and $M$. pulegium remains generally lower than those produced by the antibiotics tested. 
Table 2

Antimicrobial activity of essential oils against studied strains by disc diffusion method. Each value shows the average from three independent experiments

\begin{tabular}{|c|c|c|c|c|c|c|c|c|}
\hline \multirow{3}{*}{ Strains } & \multicolumn{8}{|c|}{ Inhibition zone [mm] } \\
\hline & \multicolumn{4}{|c|}{ Essential oils } & \multicolumn{4}{|c|}{ Antibiotics controls } \\
\hline & C. verum & E. globulus & L. angustifolia & M. pulegium & Gentamycin & Cefoxitin & Vancomycin & Imipenem \\
\hline E. coli & $26.67 \pm 1.15$ & $8 \pm 0$ & $12.34 \pm 0.58$ & $20.33 \pm 1.53$ & $18 \pm 1.15$ & $12 \pm 0$ & $19 \pm 1.15$ & $12.33 \pm 0.5$ \\
\hline S. marcescens & $29.33 \pm 1.15$ & $13.33 \pm 1.15$ & $19.67 \pm 0.58$ & $18.67 \pm 1.15$ & $19.5 \pm 1.15$ & $13.5 \pm 0.58$ & $20.6 \pm 0.58$ & $15.33 \pm 1.13$ \\
\hline E. faecalis & $36 \pm 0$ & $13 \pm 1.73$ & $18 \pm 2$ & $17.33 \pm 1.15$ & $22 \pm 1.15$ & 17.44 & $21.7 \pm 1.15$ & $9.33 \pm 0.5$ \\
\hline S. aureus & $37.67 \pm 1.53$ & $21.33 \pm 1.15$ & $20.67 \pm 1.15$ & $15.67 \pm 1.53$ & $23.6 \pm 0.58$ & $16 \pm 0$ & $19 \pm 0$ & $28.67 \pm 1.12$ \\
\hline$P$. aeruginosa & $22.67 \pm 1.15$ & $6 \pm 0$ & $6 \pm 0$ & $7.33 \pm 1.15$ & $14.7 \pm 1.15$ & $15 \pm 0.58$ & $15 \pm 0.58$ & $9.67 \pm 0.52$ \\
\hline P. mirabilis & $34.67 \pm 2.31$ & $14.67 \pm 0.58$ & $11.33 \pm 0.58$ & $12.33 \pm 0.58$ & $19 \pm 0$ & $11.55 \pm 1.15$ & $22.67 \pm 1.15$ & $11.33 \pm 1.17$ \\
\hline S. pyogenes & $39.33 \pm 1.15$ & $16.67 \pm 2.31$ & $19 \pm 1.73$ & $15.33 \pm 1.15$ & $21 \pm 0.58$ & $13 \pm 0$ & $24.67 \pm 2.31$ & $17 \pm 0$ \\
\hline K. pneumoni & $26.33 \pm 1.53$ & $9 \pm 0$ & $10 \pm 0$ & $9.33 \pm 0.58$ & $20 \pm 0$ & $17.33 \pm 1.15$ & $19.33 \pm 1.15$ & $15 \pm 0$ \\
\hline A. boumanii & $30 \pm 0$ & $10 \pm 0$ & $12.33 \pm 0.58$ & $28.67 \pm 1.15$ & $21 \pm 1.15$ & $19.44 \pm 1.15$ & $21 \pm 1.15$ & $19.33 \pm 1.15$ \\
\hline C. albicans & $27.33 \pm 1.15$ & $6 \pm 0$ & $9.67 \pm 0.58$ & $9.67 \pm 0.58$ & $17 \pm 0$ & $20 \pm 0.58$ & $17 \pm 0$ & $21 \pm 1.15$ \\
\hline S. enteritidis & $22 \pm 2$ & $9.33 \pm 1.15$ & $6 \pm 0$ & $11.33 \pm 1.15$ & $12.5 \pm 0.58$ & $18.5 \pm 0.58$ & $15 \pm 0$ & $12.33 \pm 1.23$ \\
\hline
\end{tabular}

On the other hand, the C. verum oil showed significant inhibitory effect against all bacteria and yeast tested, with a zone of inhibition ranging from 22 to $39.33 \mathrm{~mm}$. Streptococcus pyogenes is the most sensitive strain with a zone of inhibition $(39.33 \pm 1.15 \mathrm{~mm})$, followed by Staphylococcus aureus $(37.67 \pm 1.53 \mathrm{~mm})$, Enterococcus faecalis $(36 \mathrm{~mm})$, P. mirabilis $(34.67 \pm 2.31 \mathrm{~mm})$, A. boumannii $(30 \mathrm{~mm})$, Serratia marcescens $(29.33 \pm 1.15 \mathrm{~mm})$, C. albicans $(27.33 \pm 1.15 \mathrm{~mm})$, E. coli $(26.67 \pm 1.15 \mathrm{~mm})$, K. pneumoni $(26.33 \pm 1.53 \mathrm{~mm})$, P. aeruginosa $(22.67 \pm 1.15 \mathrm{~mm})$ and Salmonella enteritidis ( $22 \pm 2 \mathrm{~mm})$.

In general, E. globulus oil failed to inhibit all tested strains. Only $S$. aureus that is sensitive to this EO with an inhibition diameter of $21.33 \pm 1.15 \mathrm{~mm}$. For S. pyogenes, P. mirabilis, S. marcescens, and E. faecalis, they showed an intermediate sensitivity with a zone of inhibition of $14.67 \pm 0.58 \mathrm{~mm}, 13.33 \pm 1.15 \mathrm{~mm}$ and $13 \pm 1.73 \mathrm{~mm}$, respectively. However, A. boumannii, Salmonella, K. pneumonia, E. coli, P. aeruginosa and C. albicans show resistance to Eucalyptus EO with an inhibition diameter ranging from 6 to $10 \mathrm{~mm}$.

On the other hand, L. angustifolia EO did not show an inhibitory effect against $P$. aeruginosa, S. enteritidis, C. albicans, K. pneumoni and P. mirabilis, while lavender EO causes an intermediate effect against E. faecalis, E. coli and A. boumannii.

According to the M. pulegium essential oil, the most sensitive bacterium is A. boumnanii with a diameter of $28.67 \pm 1.15 \mathrm{~mm}$, followed by E. coli $20.33 \pm 1.53 \mathrm{~mm}$. The intermediate strains are S. marcescens, E. faecalis, S. aureus, S. pyogenes and $P$. mirabilis with a diameter ranging from $12.33 \pm 0.58 \mathrm{~mm}$ to $18.67 \pm 1.15 \mathrm{~mm}$. On the other hand, S. enteritidis, C. albicans, K. pneumoni and $P$. aeruginosa are resistant germs with a diameter of inhibition varying from $7.33 \pm 1.15 \mathrm{~mm}$ to $11.33 \pm 1.15 \mathrm{~mm}$.

\section{Minimal inhibitory, minimum bactericidal and minimum antifungal concentrations}

Results according to the MICs and MBCs of each essential oil against microbial strains studied are showed in table 3 . All microbial tested were sensitive to the essential oil of cinnamon with a MIC ranging from $0.20 \mathrm{mg} / \mathrm{ml}$ to $1.56 \mathrm{mg} / \mathrm{ml}$. The highest concentration of cinnamon oil $1.56 \mathrm{mg} / \mathrm{ml}$ was effective against $E$. coli, $P$. aeruginosa, $S$. enteritidis and $S$. pyogenes. The $C$. verum value of MIC $0.20 \mathrm{mg} / \mathrm{ml}$ was observed in E. faecalis, P. mirabilis and A. boumannii. The MICs recorded for E. globules and L. angustifolia EOs range from $25 \mathrm{mg} / \mathrm{ml}$ as a minimum value to $50 \mathrm{mg} / \mathrm{ml}$ as the maximum value. The MIC obtained by the HE of M. pulegium varies between $3.13 \mathrm{mg} / \mathrm{ml}$ and $25 \mathrm{mg} / \mathrm{ml}$, recorded respectively in A. boumannii and $S$. pyogenes. The CMBs values of essential oils vary from strain to strain. At low concentrations, ranging from 0.2 to $3.13 \mathrm{mg} / \mathrm{ml}$ the $\mathrm{EO}$ of C. verum showed the most important bactericidal effect. Thus, among all essential oils the $C$. verum exhibited a Fungicidal 
Table 3

Minimal inhibitory, minimum bactericidal and minimum antifungal concentrations $(\mathrm{mg} / \mathrm{ml})$ of selected essential oils determined by broth dilution methods

\begin{tabular}{|c|c|c|c|c|c|c|c|c|c|c|c|c|}
\hline \multirow[b]{3}{*}{ Strains } & \multicolumn{12}{|c|}{ Essential oils } \\
\hline & \multicolumn{3}{|c|}{ C. verum } & \multicolumn{3}{|c|}{ E. globulus } & \multicolumn{3}{|c|}{ L. angustifolia } & \multicolumn{3}{|c|}{ M. pulegium } \\
\hline & MIC & $\begin{array}{l}\text { MBC, } \\
\text { MFC }\end{array}$ & $\begin{array}{l}\text { MBC } \\
\text { or } \\
\text { MFC/ } \\
\text { MIC }\end{array}$ & MIC & $\begin{array}{l}\text { MBC, } \\
\text { MFC }\end{array}$ & $\begin{array}{l}\text { MBC or } \\
\mathrm{MFC/} \\
\mathrm{MIC}\end{array}$ & MIC & $\begin{array}{l}\text { MBC, } \\
\text { MFC }\end{array}$ & $\begin{array}{l}\text { MBC or } \\
\mathrm{MFC/} \\
\mathrm{MIC}\end{array}$ & MIC & $\begin{array}{l}\text { MBC, } \\
\text { MFC }\end{array}$ & $\begin{array}{l}\text { MBC or } \\
\text { MFC/ } \\
\text { MIC }\end{array}$ \\
\hline E. coli & 1.56 & 3.13 & 2 & - & - & - & - & - & - & 6.25 & 6.25 & 1 \\
\hline S. marcescens & 0.39 & 0.78 & 2 & - & - & - & 25 & 25 & 1 & 6.25 & 6.25 & 1 \\
\hline E. faecalis & 0.20 & 0.78 & 3.9 & - & - & - & 25 & $>50$ & 1 & 6.25 & 12.5 & 2 \\
\hline S. aureus & 0.78 & 3.13 & 4 & 50 & $>50$ & $>1$ & 25 & 50 & 2 & 12.50 & 50 & $>4$ \\
\hline P. aeruginosa & 1.56 & 1.56 & 1 & - & - & - & - & - & - & - & - & - \\
\hline P. mirabilis & 0.20 & 0.20 & 1 & 25 & 25 & 1 & - & - & - & - & - & - \\
\hline S. pyogenes & 1.56 & 3.13 & 0.32 & 50 & 50 & 1 & 50 & 50 & 1 & 25 & 50 & 2 \\
\hline K. pneumoni & 0.39 & 3.13 & 8 & - & - & - & - & - & - & - & - & - \\
\hline A. boumanii & 0.20 & 0.39 & 1.95 & - & - & - & - & - & - & 3.13 & 3.13 & 1 \\
\hline C. albicans & 0.39 & 0.39 & 1 & - & - & - & - & - & - & - & - & - \\
\hline S. enteritidis & 1.56 & 3.13 & 2 & - & - & - & - & - & - & - & - & - \\
\hline
\end{tabular}

Concentration (MFC) $0.39 \mathrm{mg} / \mathrm{ml}$. For the M. pulegium $\mathrm{EO}$ the $\mathrm{MBC}$ varies from 3.13 to $50 \mathrm{mg} / \mathrm{ml}$, then those of L. angustifolia and E. globulus it oscillates between 25 and $50 \mathrm{mg} / \mathrm{ml}$.

In order to determine the bacteriostatic, bactericidal or effect of the HE, we calculated the MBC/MIC ratio (tab. 2). Indeed, if $\mathrm{MBC} / \mathrm{MIC}$ is less than 4 , the effect is bactericidal or and if $\mathrm{MBC} / \mathrm{MIC}$ is greater than or equal to 4 , the effect is bacteriostatic. In generally, results indicate that only C. verum $\mathrm{EO}$ that showed a bactericidal or bacteriostatic effect on all bacterial and C. albicans strains studied. The bactericidal and fungicidal effect of this oil is recorded in both gram negative and positive bacterial strains and C. albicans. While the bacteriostatic effect is recorded in S. aureus.

\section{DISCUSSION}

Plants produce an enormous array of functional relevant secondary metabolites such as essential oils (phytochemicals) that exhibit a diversity of medicinal properties [14]. In this study, the antimicrobial activity of four EOs was investigated against clinical bacteria and Candida albicans. The obtained results showed that $C$. verum essential oil exhibited a strong activity against all pathogens, with a zone of inhibition ranging from 22 to $39.33 \mathrm{~mm}$. Among all microorganisms tested $S$. pyogenes is the most sensitive strain with a zone of inhibition $(39.33 \pm 1.15 \mathrm{~mm})$. According to MICs values, all bacteria and yeast tested were sensitive to cinnamon with a MIC ranging from $0.20 \mathrm{mg} / \mathrm{ml}$ to $1.56 \mathrm{mg} / \mathrm{ml}$. At low concentrations, ranging from 0.2 to $3.13 \mathrm{mg} / \mathrm{ml}$, the $\mathrm{EO}$ of C. verum showed the most important bactericidal and fungicidal effect. This result consistent with precious study, which showed that the cinnamon essential oil, extracted from the bark and leaves, had considerable ability to inhibit the growth of foodborne pathogens [15-17]. Other studies Matan et al. [18] have shown that cinnamon had strong and consistent inhibitory effects against various pathogens. In one study, Oulkheir et al. [19] reported that cinnamon possesses an important antimicrobial activity against Gramnegative bacteria: Escherichia coli (ATCC 25922), K. pneumoniae (ATCC 10031), P. aeruginosa (ATCC 27853), Salmonelle spp. and Gram-positive bacteria; Streptococcus and Staphylococcus aureus (ATCC 25923) with an inhibition zones ranging from 26 to $32 \mathrm{~mm}$. Other examples are described in the literature by different authors. Matan et al. [18], Mau et al. [20] Sathishkumar et al. [21] revealed that cinnamon oil have exhibited higher antimicrobial activity. According to Singh et al. [15] cinnamon is also used as a flavoring substance. These authors reported that in 
addition to flavor, it could also be used as antioxidant agent to prevent food oxidation. Investigators have found that the cinnamon essential oil, extracted from the bark and leaves, had considerable ability to inhibit the growth of foodborne pathogens [15-17]. Even though earlier studies have reported better antimicrobial activity for E. globulus oil [22]. Our study showed least inhibitory activity of E. globulus. It was found that eucalyptus oil failed to inhibit all tested strains. Only Staphylococcus aureus that is sensitive to this EO with an inhibition diameter of $21.33 \pm 1.15 \mathrm{~mm}$. However, Acinetobacter boumannii, Salmonella enteritidis, Klebsiella pneumoniae, Escherichia coli, Pseudomonas aeruginosa and Candida albicans show resistance.

Results obtained from this study showed that essential oil from L. augustifolia did not show antibacterial properties against $P$. aeruginosa, Salmonella, C. albicans, K. pneumoniae and $P$. mirabilis. In contrast, this EO causes an inhibiting effect against other strains. According to the M. pulegium essential oil, the most sensitive bacterium is A. boumannii with a diameter of $28.67 \pm 1.15 \mathrm{~mm}$, followed by E. coli $20.33 \pm 1.53 \mathrm{~mm}$. Finding of this study indicates that MICs of M. pulegium varies between $3.13 \mathrm{mg} / \mathrm{ml}$ and $25 \mathrm{mg} / \mathrm{ml}$, recorded respectively in A. boumannii and S. pyogenes and MBCs varies from 3.13 to $50 \mathrm{mg} / \mathrm{ml}$.

The regular use of antimicrobials for treatment therapy or prophylaxis promotes the development of antibiotics bacterial resistance. Results obtained from this study were particularly interesting. Antibacterial activity of essential oils especially those of cinnamon against studied strains, support their potential use as a remedy for bacterial infectious diseases.

Conflict of interest: Authors declare no conflict of interest.

\section{REFERENCES}

1. Dolinger DL, Jacobs AA. Molecular diagnostics and active screening for health care-associated infections: Stepping-Up the Game. Lab Medicine 2010; 42:267-272. doi: http//dx.doi.org/10.1309/ LMH144ZOETKVQCJU

2. Pitout D, Laupland KB. Extended-spectrum $\beta$-lactamase-producing Enterobacteriaceae: an emerging public-health concern. Lancet Infect Dis 2008; 8:(3):159-166. doi: http://dx.doi. org/10.1016/S1473-3099(08)70041-0
3. Berger J, Diab-Elschahawi M, Blacky A, Permicka E, Spertini V, Assadian O et al. A matched prospective cohort study on Staphylococcus aureus and Escherichia coli bloodstream infections: extended perspectives beyond resistance. Am J Infect Control 2010; 8:(10) 839-845. doi: http:// dx.doi.org/10.1016/j.ajic.2010.04.212

4. David MZ, Daum RS. Community-associated methicillin-resistant Staphylococcus aureus: epidemiology and clinical consequences of an emerging epidemic. Clin Microbiol Rev 2010; 23(3):616-687. doi: http://dx.doi.org/10.1128/ CMR.00081-09

5. Dorman HJ.D, Deans SG. Antimicrobial agents from plants antibacterial activity of plant volatile oils. J Appl Microbiol 2000; 88:308-316.

6. Rauha JP, Remes S, Hemonen M, Hopia A, Kahkonen M, Kujala T, et al. Antimicrobial effects of Finnish plant extracts containing flavonoids and other phenolic compounds. Int J Food Microbiol 2000; 56:3-12.

7. Nerio LS, Olivero-Verbel J, Stashenko E. Repellent activity of essential oils: a review. Bioresour Technol 2010; 101(1):372-378. doi: http://dx.doi. org/10.1016/j.biortech.2009.07.048

8. Abdollahzadeh E, Rezaei M, Hosseini H. Antibacterial activity of plant essential oils and extracts: The role of thyme essential oil, nisin, and their combination to control Listeria monocytogenes inoculated in minced fish meat. Food Control 2014; 35(1):177-183.

9. Banerjee P, Satapathy M, Mukhopahayay A, Das P. Leaf extract mediated green synthesis of silver nanoparticles from widely available Indian plants: synthesis, characterization, antimicrobial property and toxicity analysis. Biores Bioprocess 2014; 1:3. doi: http://dx.doi.org/10.1186/ s40643-014-0003-y

10. Jagtap U B, Bapat V A. Green synthesis of silver nanoparticles using Artocarpus heterophyllus Lam. seed extract and its antibacterial activity. Industr Crops Prod 2013; 46:132-137. doi: http:// dx.doi.org/10.1016/j.indcrop.2013.01.019

11. Sienkiewicz M, Głowacka A, Kowalczyk E, Wiktorowska-Owczarek A, Jóźwiak-Bębenista M, Eysakowska M. The biological activities of 
cinnamon, geranium and lavender essential oils. Molecules 2014; 19(12):20929-20940. doi: http:// dx.doi.org/10.3390/molecules191220929

12. European Pharmacopoeia. Vol. 3, Maissonneuve SA: Sainte-Ruffine, 1975:68.

13. De Billerbeck VG. Huiles essentielles et bactéries résistantes aux antibiotiques. Phytothérapie 2007; 5(5):249-253. doi: http://dx.doi.org/10.1007/ s10298-007-0265-z

14. Sultanbawa Y. Plant antimicrobials in food applications: minireview. In: Méndez-Vilas A. (ed.): Science against microbial pathogens: communicating current research and technological advances. Badajoz, Spain: Formatex Research Center:1084-1093.

15. Hill LE, Gomes C, Taylor TM. Characterization of beta-cyclodextrin inclusion complexes containing essential oils (trans-cinnamaldehyde, eugenol, cinnamon bark, and clove bud extracts) for antimicrobial delivery applications. LWTFood Sci Technol 2013; 51(1):86-93. doi: http:// dx.doi.org/10.1016/j.lwt.2012.11.011

16. Singh G, Maurya S, Catalan CA. A comparison of chemical, antioxidant and antimicrobial studies of cinnamon leaf and bark volatile oils, oleoresins and their constituents. Food Chem Toxicol 2007; 45(9):1650-1661. doi: http:// dx.doi. org/10.1016/j.fct.2007.02.031

17. Chang ST, Chen PF, Chang SC. Antibacterial activity of leaf essential oils and their constituents from Cinnamomum osmophloeum. J Ethnopharmacol 2001; 77(1):123-127.
18. Matan N, Rimkeeree H, Mawson AJ, Chompreeda P, Haruthaithanasan V, Parker M. Antimicrobial activity of cinnamon and clove oils under modified atmosphere conditions. Int J Food Microbiol 2006; 107:180-185. doi: http://dx.doi. org/10.1016/j.ijfoodmicro.2005.07.007

19. Oulkheir S, Aghrouch M, El Mourabit F, Dalha F, Graich H, Amouch F et al. Antibacterial activity of essential oils extracts from cinnamon, thyme, clove and geranium against a gram negative and gram positive pathogenic bacteria. J Dis Med Plants, Special Issue: New Vistas of Research in Ayurveda System of Medicine 2017; 3(2-1):1-5. doi: http:// dx.doi.org/10.11648/j.jdmp.s.2017030201.11

20. Mau JL, Chen CP, Hsieh PC. Antimicrobial effect of extracts from Chinese chive, cinnamon, and cornifructus. J Agric Food Chem 2001; 49(1):183-188.

21. Sathishkumar M, Sneha K, Won SW, Cho CW, Kim S, Yun YS. Cinnamon zeylanicum bark extract and powder mediated green synthesis of nano-crystalline silver particles and its bactericidal activity. Colloids Surf B Biointerfaces 2009, 73(2):332-338. doi: http://dx.doi.org/10.1016/j. colsurfb.2009.06.005

22. Takarada K, Kimizuka R, Takahashi N, Honma K, Okuda K, Kato T. A comparison of the antibacterial efficacies of essential oils against oral pathogens. Oral Microbiol Immunol 2002; 19:61-64. doi: http://dx.doi.org/10.1046/j.09020055.2003.00111.x 